\title{
Functionalized Nanoparticles for Drug Delivery, One- and Two-photon Photodynamic Therapy as a Promising Treatment of Retinoblastoma
}

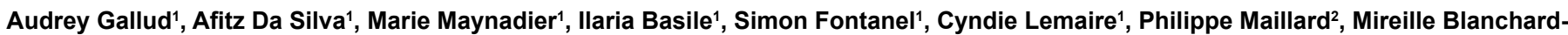 \\ Desce $^{3}$, Olivier Mongin ${ }^{3}$, Alain Morère ${ }^{1}$, Jean-Olivier Durand ${ }^{4}$, Laurence Raehm ${ }^{4}$, Marcel Garcia' and Magali Gary-Bobo ${ }^{1 *}$
}

${ }^{1}$ Institut des Biomolécules Max Mousseron, CNRS UMR5247, Université de Montpellier 1, Université de Montpellier 2, Faculté de Pharmacie, 15 avenue Charles Flahault, 34093 Montpellier, France

${ }^{2}$ Institut Curie, Section de Recherches, Centre Universitaire, Université Paris-Sud, F-91405 Orsay, France

${ }^{3}$ Chimie et Photonique Moléculaires, CNRS UMR 6510, Campus de Beaulieu, Université Rennes 1, 35042 Rennes Cedex, France

${ }^{4}$ Institut Charles Gerhardt Montpellier, UMR 5253, CNRS-UM2-ENSCM-UM1, CC1701 Place Eugène Bataillon, 34095 Montpellier Cedex 05 , France

\begin{abstract}
Retinoblastoma is a rare cancer triggered by genetic mutation that forms in the eyes of children. In industrialized countries, $95 \%$ of patients are cured by chemotherapy and conservative treatments. However these treatments can increase the risk of secondary tumors in patients with a constitutional alteration of the retinoblastoma gene $R b 1$. Photodynamic therapy (PDT) represents a therapeutic approach and may reduce the incidence of secondary tumors. PDT is an established cancer treatment based on the light activation of a photosensitizing agent thus generating cytotoxic reactive oxygen species that cause cellular damage. We focused on mesoporous silica nanoparticles (MSN) for one-photon excited PDT combined with drug delivery and carbohydrate targeting applied on retinoblastoma. We demonstrated that bitherapy (camptothecin delivery and PDT) performed with MSN was efficient in inducing retinoblastoma cell death. Alternatively, MSN designed for two-photon excited PDT were also studied and irradiation in near-infrared at low fluency efficiently killed retinoblastoma cancer cells. These data provide new evidences of the potential of functionalized and targeted MSN for treatment of retinoblastoma and could lead to propose a non-invasive therapy with reduced side effects.
\end{abstract}

Keywords: Mesoporous silica nanoparticles; Two-photon; Photodynamic therapy; Drug delivery; Mannose; Galactose; Targeting; Retinoblastoma

\section{Introduction}

Retinoblastoma is the most common intraocular malignant tumor in childhood with an incidence of 1 for 20,000 births which occurs during the first five years of life. The retinoblastoma cell of origin has been debated for over a century; however, we now have a detailed understanding of the neuronal pathways that are deregulated in the primitive cells of the retina. The role of genomic instability of the retinoblastoma gene $R b 1$ localized on chromosome $13 \mathrm{q}$ and the most relevant epidemiological issues concerning retinoblastoma have recently been pointed out to explain the variegated clinical expression of the disease [1-3]. The most common signs of retinoblastoma are a visible whiteness in the pupil called leukocoria and a strabismus. The unilateral form of the disease represents $70 \%$ of cases; however $30 \%$ of children develop the bilateral form in both eyes.

Retinoblastoma is often curable when it is diagnosed early, but if it is not treated promptly, this cancer can spread beyond the eye to other parts of the body. When tumor is exclusively localize into the eye, the majority of patients can be cured by therapeutic treatments including enucleation or conservative treatments using, intravenous and/or intraarterial chemotherapy [4,5], cryotherapy [6], local thermotherapy or brachytherapy. External beam radiotherapy is increasingly restricted due to the risk of late effects. The potential risks of late effects associated with chemotherapy and carboplatin include increased risk of second cancer, as well as short-term important side effects. Besides, due to the lack of blood supply to vitreous seeding, chemotherapy drugs could not reach the vitreous body through blood-retinal barrier. This is one of the important limiting factors which triggered intravenous chemotherapy as a new injection technique for vitreous disease in retinoblastoma [7].

In this context, nanotechnologies seem to offer new perspectives for the treatment of retinoblastoma [8]. From day to day nanomedicine appears as a non-invasive therapeutic solution. Encapsulated in nanocarriers, drugs could target only cancer cells by considering the tumor microenvironment, the biomarkers overexpressed on the cancer cells and different physical methods for non-invasive therapies [9]. The photodynamic therapy (PDT) is one of the biophysical methods of nanoparticle activation based on the combination of three partners which are a light-activated photosensitizer encapsulated in the nanoparticle, the surrounding oxygen able to produce a toxic compound and an energy laser beam to induce activation [10]. The activated photosensitizers transfer their energy to molecular oxygen which forms highly reactive singlet oxygen and other reactive oxygen species. This phenomenon induces the death of cells having internalized photosensitizers. It is important to note that the photosensitizers are photoactivable by a near-infrared wavelength that is non-mutagenic [11]. Since few years, the specific targeting of nanomedicine to carbohydrate receptors performs a useful strategy for improving the efficacy of treatments. Recently, carbohydrate-targeted systems have been developed to target cancer. Nanoparticles loaded with photosensitizers and covalently linked with mannose residues were synthesized and their improvement uptake in cancer cells was demonstrated in vitro and in vivo [12-15].

*Corresponding author: Magali Gary-Bobo, Institut des Biomolécules Max Mousseron, CNRS UMR5247, Université de Montpellier 1, Université de Montpellier 2, Faculté de Pharmacie, 15 avenue Charles Flahault, 34093 Montpellier, France, E-mail: magali.gary-bobo@inserm.fr

Received June 14, 2013;

Citation: Gallud A, Silva $\overline{A D D}$, Maynadier M, Basile I, Fontanel S, et al. (2013) Functionalized Nanoparticles for Drug Delivery, One- and Two-photon Photodynamic Therapy as a Promising Treatment of Retinoblastoma. J Clin Exp Ophthalmol 4: 288. doi:10.4172/2155-9570.1000288

Copyright: $\odot 2013$ Gallud A, et al. This is an open-access article distributed under the terms of the Creative Commons Attribution License, which permits unrestricted use, distribution, and reproduction in any medium, provided the original author and source are credited. 
Citation: Gallud A, Silva AD, Maynadier M, Basile I, Fontanel S, et al. (2013) Functionalized Nanoparticles for Drug Delivery, One- and Two-photon Photodynamic Therapy as a Promising Treatment of Retinoblastoma. J Clin Exp Ophthalmol 4: 288. doi:10.4172/2155-9570.1000288

Page 2 of 4

In this study, we followed-up of the efficiently internalization of mannose functionalized mesoporous silica nanoparticles (MSN) in solid tumor. Then, we focused on MSN potential for one-photon PDT combined with drug delivery and carbohydrate targeting applied on a human retinoblastoma cell line. A comparison with MSN designed for two-photon PDT indicated the potential of this technique to efficiently kill retinoblastoma cancer cells using irradiation at low fluency.

\section{Materials and Methods}

\section{Synthesis of MSN}

Different nanoparticles were designed linked or not with galactose (Gal) or mannose (Man) residues and loaded with or without fluorescein (FITC), camptothecin (CPT), one-photon photosensitizer (1rPS) or two-photon photosensitizer (2rPS). Synthesizes of MSNFITC, MSN-FITC-Man, MSN-(CPT)-Gal or -Man, MSN-(CPT+1rPS)Gal or -Man, MSN-(1rPS)-Man and MSN-(2rPS)-Man were already described in our previous work $[8,12,13]$.

\section{Cell culture conditions}

Human retinoblastoma cancer cells (Y-79) were purchased from ATCC (American Type Culture Collection, Manassas, VA). Cells were cultured in Roswell Park Memorial Institute 1640 (RPMI 1640) culture medium supplemented with $20 \%$ fetal bovine serum, 100 U.mL ${ }^{-1}$ streptomycin and allowed to grow in humidified atmosphere at $37^{\circ} \mathrm{C}$ under $5 \% \mathrm{CO}_{2}$.

\section{Distribution of MSN in xenografted nude mice}

Eight nude mice were subcutaneously injected in the flank with $10^{6}$ cells of pancreatic cancer cell line (capan-1). One month after cancer cell injection, 6 mice had developed subcutaneous tumors with a mean tumor volume of $500 \mathrm{~mm}^{3}$. Mice $(\mathrm{n}=2)$ were injected intravenously with $200 \mu \mathrm{L}$ of physiological serum alone (control) or supplemented with MSN-FITC $(n=2)$ or MSN-FITC-Man $(n=2)\left(16 \mathrm{mg}^{-\mathrm{kg}^{-1}}\right)$. Three hours later, mice were sacrificed and tumor, kidneys and liver were removed. Then organs were crushed and distribution of MSN was quantified by measurement of FITC intensity, excitation $485 \mathrm{~nm}$ and emission $538 \mathrm{~nm}$, through a fluorescence microplate reader (Gemini, Molecular Devices).

\section{PDT one and two-photon excitation and phototoxicity measurement}

For monophotonic irradiation, Y-79 cells were seeded into 96-well plates at 10,000 cells per well in $100 \mu \mathrm{L}$ culture medium and allowed to grow for $24 \mathrm{~h}$. Then cells were incubated for $24 \mathrm{~h}$ with or without $20 \mu \mathrm{g} . \mathrm{mL}^{-1} \mathrm{MSN}$. After incubation, cells were submitted or not to laser irradiation for $30 \mathrm{~min}\left(650 \mathrm{~nm}, 90{\mathrm{~J} . \mathrm{cm}^{-2}}^{-2}\right.$. For two-photon excitation irradiation, Y-79 cells were seeded into 384 multi-well glass bottom (thickness $0.17 \mathrm{~mm}$ ), with a black polystyrene frame, 2,000 cells per well in $50 \mu \mathrm{L}$ culture medium and allowed to grow for $24 \mathrm{~h}$. Cells were then incubated for $24 \mathrm{~h}$ with or without $20 \mu \mathrm{g} \cdot \mathrm{mL}^{-1} \mathrm{MSN}$. After incubation with MSN, cells were submitted or not to laser irradiation. Scanned areas were $1.5 \times 1.5 \mathrm{~mm}^{2}$. The entire area of the well was irradiated at $760 \mathrm{~nm}$ by 3 scans of $1.25 \mathrm{~s}$ each. The average power delivered to the sample was measured with a thermoelectric optical energy meter and was $47 \mathrm{~J} . \mathrm{cm}^{-2}$. The laser beam is focused by a microscope objective lens (10X, NA 0.4). Two day after irradiations (one- or two-photon), a MTS assay was performed to evaluate the phototoxicity of MSN by adding $333 \mu \mathrm{g} \cdot \mathrm{mL}^{-1}$ of tetrazolium salt (CellTiter 96 aqueous One Solution Reagent, Promega) solution. Cells were incubated $3 \mathrm{~h}$ at $37^{\circ} \mathrm{C}$ and the absorbance was read at $490 \mathrm{~nm}$ in a plate reader to determine the formazan concentration, which is proportional to the number of living cells.

\section{Cytotoxicity assay for drug delivery}

For these experiments, Y-79 cells were seeded into 96-well plates at 10,000 cells per well in $100 \mu \mathrm{L}$ culture medium and allowed to grow for $24 \mathrm{~h}$. Then cells were incubated at different times with or without $20 \mu \mathrm{g} . \mathrm{mL}^{-1} \mathrm{MSN}$. To evaluate the cytotoxicity of MSN, a MTS assay was performed as described above.

\section{Statistical analysis}

Statistical analysis was performed using the Student's $t$ test to compare paired groups of data. A $p$ value of $<0.05$ was considered to be statistically significant.

\section{Results}

In previous work, we demonstrated the lectin-mediated cellular uptake of functionalized nanoparticles and the specific endocytosis involving carbohydrate receptors expressed by cancer cells [8]. Here, we designed MSN encapsulated with fluorescein (FITC) or camptothecin (CPT) or a porphyrin derivative one-photon photosensitizer (1rPS) [11] or a fluorene derivative two-photon photosensitizer (2rPS) [16] grafted with mannose or galactose through a squarate linker (Figure 1). In this work, we first verified the potential accumulation of MSN linked with mannose residue into mice tumors. For this, nude mice with subcutaneous tumors were intravenously injected with FITC-loaded MSN covered or not with mannose (Figure 1A). Three hours after injection we observed a higher accumulation in tumor of mice treated with MSN-FITC-Man, while MSN-FITC was mainly retained by liver (Figure 2). This demonstrates the high tumor-targeting efficiency of mannose residues grafted at the surface of MSN.

Then, we focused on Y-79 retinoblastoma cells in order to provide new evidences of the potential of targeted MSN for the treatment of retinoblastoma. To evaluate the efficiency of drug delivery combining
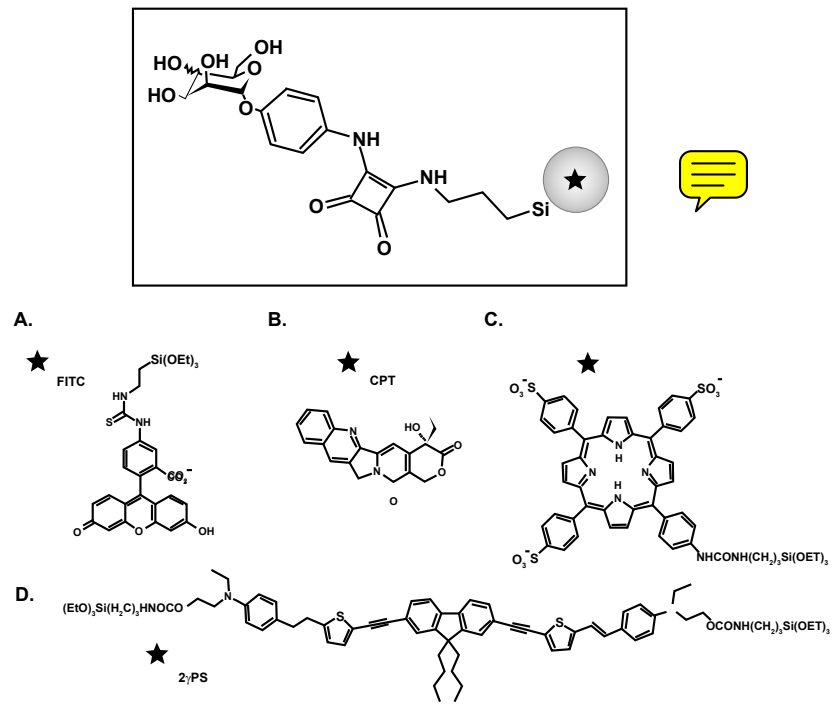

Figure 1: Structure of MSN-(CPT)-Gal/Man, MSN-(CPT+1 $r P S)-G a l /$ Man, MSN-(1rPS)-Man and MSN-(2rPS)-Man nanoparticles. A. Structure of fluorescein (FITC) B. Structure of camptothecin (CPT) C. Structure of porphyrin derivative one photon photosensitizer (1rPS) D. Structure of fluorene derivative two photon photosensitizer (2rPS). 
Citation: Gallud A, Silvd $\bar{\equiv}$ Maynadier M, Basile I, Fontanel S, et al. (2013) Functionalized Nanoparticles for Drug Delivery, One- and Two-photon Photodynamic Therapy as a Promising Treatment of Retinoblastoma. J Clin Exp Ophthalmol 4: 288. doi:10.4172/2155-9570.1000288

to PDT, cells were treated with MSN-(CPT)-Gal or -Man, MSN(CPT+1rPS)-Gal or -Man (Figure 1B and 1C). CPT-drug delivery on Y-79 cells treated with MSN-(CPT)-Gal or -Man induced $24 \%$ and $26 \%$ of cell death, respectively. In contrast, when irradiated MSN-(CPT+1rPS)-Gal or -Man induced $68 \%$ and $58 \%$ of cell death, respectively (Figure 3$)$. We have verified that MSN-(CPT+1rPS)-Gal/ Man were no more toxic in the dark than MSN-(CPT)-Gal/Man and that irradiation alone was not toxic for cells (data not shown). These results suggest that a high therapeutic potential of synergistic use of drug delivery and PDT can be provide using the same MSN.

We next compared the PDT efficiency between $2 \gamma \mathrm{PS}$ encapsulated mannose-grafted MSN (Figure 1D) and 1rPS-loaded one (Figure 1C). Cells were incubated for $24 \mathrm{~h}$ with $20 \mu \mathrm{g} \cdot \mathrm{mL}^{-1}$ of MSN-(1rPS)-

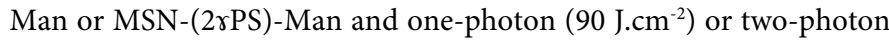
$\left(47{\mathrm{~J} . \mathrm{cm}^{-2}}^{2}\right.$ irradiations were performed. As shown in Figure 4, the photodynamic therapeutic potential of MSN-(2rPS)-Man is clearly higher even if power is less intense, $67 \%$ of cell death, than MSN(1rPS)-Man, 28\% of cell death. The nanoparticles were found to be non-toxic without irradiation and irradiation alone did not damage the cells (data not shown). These results indicate that MSN designed for two-photon excitation PDT present interesting therapeutic properties to kill retinoblastoma cancer cells.

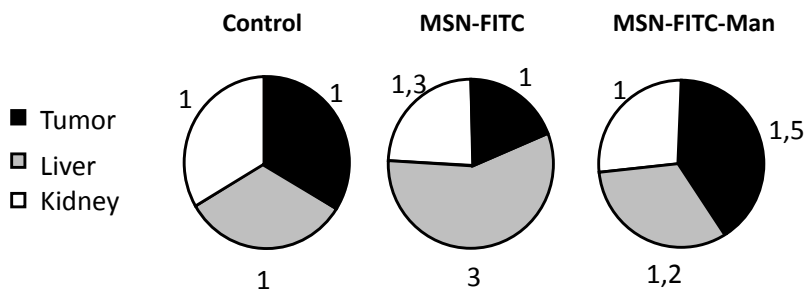

Figure 2: Distribution of nanoparticles intravenously injected in tumorxenografted nude mice. MSN were covalently loaded with fluorescein (FITC) and grafted or not with mannose (Man). Mice were treated with $16 \mu \mathrm{g} \cdot \mathrm{mL}^{-1}$ and sacrificed $3 \mathrm{~h}$ after injection.

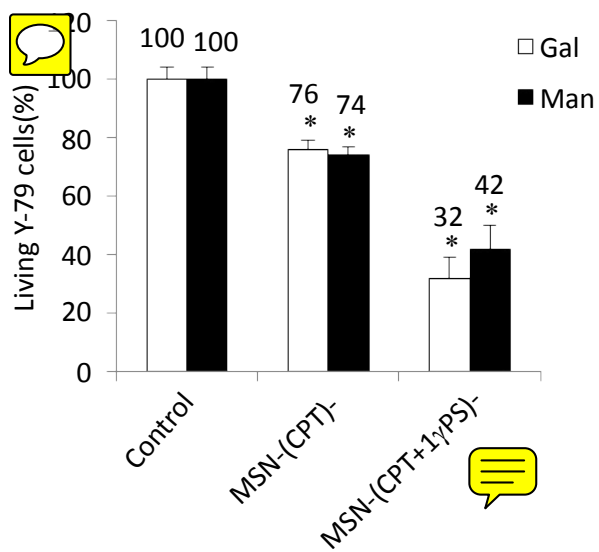

Figure 3: Additional effect of drug delivery and one photon PDT on retinoblastoma cells. Y-79 cells were incubated or not (control) with 20 $\mu \mathrm{g} \cdot \mathrm{mL}^{-1}$ for $24 \mathrm{~h}$ with MSN-(CPT)-Gal or -Man and MSN-(CPT+1rPS)-Gal or -Man and then submitted to laser irradiation $\left(650 \mathrm{~nm}, 90 \mathrm{J.cm}^{-2}\right)$. Cells were allowed to grow for 2 days and cell viability was quantified. Statistically different ${ }^{*} p<0.05$ from control (Student's test).

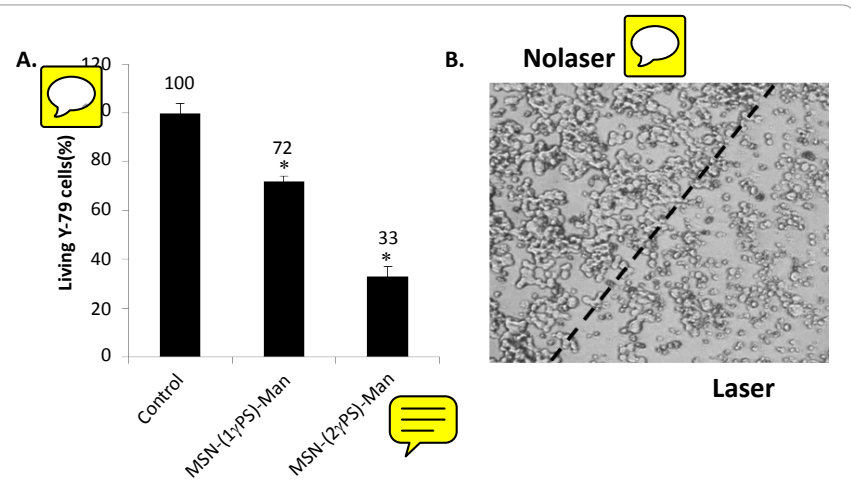

Figure 4: Comparison of PDT effect between two photon excitation and one photon excitation on retinoblastoma cells. A. Y-79 cells were incubated or not (control) with $20 \mu \mathrm{g} \cdot \mathrm{mL}^{-1}$ for $24 \mathrm{~h}$ with MSN-(1rPS)-Man or MSN-(2rPS)-Man, and then irradiated at $650 \mathrm{~nm}\left(30 \mathrm{~min}, 90 \mathrm{J.cm}^{-2}\right)$ or at 760 $\mathrm{nm}\left(3 \times 1.25 \mathrm{~s}, 47 \mathrm{~J} . \mathrm{cm}^{-2}\right)$, respectively. Cell viability was quantified two days after. Statistically different ${ }^{*} p<0.05$ from control (Student's test). B. Irradiated zone showing photo-induced cell death.

\section{Conclusion}

In this study, a significant therapeutic synergy between onephoton PDT combined with CPT-drug delivery has been revealed. Furthermore, promising results of two-photon PDT were obtained at $760 \mathrm{~nm}$ irradiation and low fluency $47 \mathrm{~J} . \mathrm{cm}^{-2}$. Using of two-photon photosensitizers the window for excitation is extended into the near infrared region, thereby making the process more viable to be used on the human body. The data provide new evidences of the potential of functionalized and targeted MSN for treatment of retinoblastoma and could lead to propose a non-invasive therapy. Considering their sizes and properties in release, specific targeting and minimizing or eliminate side effects resulting directly from current administration methods, MSN appear to be the most promising tool to meet the primary requirements of an ideal ocular delivery system [17]. Current investigations are carried out to identify which carbohydrate receptors are overexpressed in retinoblastoma to improve therapeutic efficiency.

\section{Acknowledgement}

This study was supported by ANR PNANO 07-102, GDR "GDR CNRS 3049 Photomed "Médicaments photoactivables - Photochimiothérapie", Association pour la Recherche sur le Cancer" n SFI20101201906 and the non-profit organization "Rétinostop".

\section{References}

1. De Francesco S, Galluzzi P, Del Longo A, Piozzi E, Renieri A, et al. (2012) $13 q$ deletion syndrome and retinoblastoma in identical dichorionic diamniotic monozygotic twins. Eur J Ophthalmol 22: 857-860.

2. Mastrangelo D, De Francesco S, Di Leonardo A, Lentini L, Hadjistilianou T (2008) The retinoblastoma paradigm revisited. Med Sci Monit 14: RA231-240.

3. McEvoy J, Flores-Otero J, Zhang J, Nemeth K, Brennan R, et al. (2011) Coexpression of normally incompatible developmental pathways in retinoblastoma genesis. Cancer Cell 20: 260-275.

4. Abramson DH, Marr BP, Dunkel IJ, Brodie S, Zabor EC, et al. (2011) Intraarterial chemotherapy for retinoblastoma in eyes with vitreous and/or subretinal seeding: 2-year results. Br J Ophthalmol 96: 499-502.

5. Choi S, Han JW, Kim H, Kim BS, Kim DJ, et al. (2013) Combined chemotherapy and intra-arterial chemotherapy of retinoblastoma. Korean J Pediatr 56: 254259

6. Shields JA, Shields CL, De Potter P (1993) Cryotherapy for retinoblastoma. Int Ophthalmol Clin 33: 101-105.

7. Munier FL, Gaillard MC, Balmer A, Soliman S, Podilsky G, et al. (2012) 
Citation: Gallud A, Silva $\overline{\mathrm{KD}}$, Maynadier M, Basile I, Fontanel S, et al. (2013) Functionalized Nanoparticles for Drug Delivery, One- and Two-photon Photodynamic Therapy as a Promising Treatment of Retinoblastoma. J Clin Exp Ophthalmol 4: 288. doi:10.4172/2155-9570.1000288

Intravitreal chemotherapy for vitreous disease in retinoblastoma revisited: from prohibition to conditional indications. Br J Ophthalmol 96: 1078-1083.

8. Gary-Bobo M, Hocine O, Brevet D, Maynadier M, Raehm L, et al. (2012) Cancer therapy improvement with mesoporous silica nanoparticles combining targeting, drug delivery and PDT. Int J Pharm 423: 509-515.

9. Gary-Bobo M, Vaillant O, Maynadier M, Basile I, Gallud A, et al. (2013) Targeting multiplicity: the key factor for anti-cancer nanoparticles. Curr Med Chem 20: 1946-1955.

10. Wilson BC, Patterson MS (2008) The physics, biophysics and technology of photodynamic therapy. Phys Med Biol 53: R61-109.

11. Laville I, Pigaglio S, Blais JC, Doz F, Loock B, et al. (2006) Photodynamic efficiency of diethylene glycol-linked glycoconjugated porphyrins in human retinoblastoma cells. J Med Chem 49: 2558-2567.

12. Brevet D, Gary-Bobo M, Raehm L, Richeter S, Hocine O, et al. (2009) Mannose-targeted mesoporous silica nanoparticles for photodynamic therapy. Chem Commun (Camb) 28: 1475-1477.
13. Gary-Bobo M, Mir Y, Rouxel C, Brevet D, Basile I, et al. (2011) Mannosefunctionalized mesoporous silica nanoparticles for efficient two-photon photodynamic therapy of solid tumors. Angew Chem Int Ed Engl 50: 1142511429.

14. Hocine O, Gary-Bobo M, Brevet D, Maynadier M, Fontanel S, et al. (2010) Silicalites and Mesoporous Silica Nanoparticles for photodynamic therapy. Int J Pharm 402: 221-230.

15. Lupu M, Thomas CD, Maillard P, Loock B, Chauvin B, et al. (2009) 23Na MR longitudinal follow-up of PDT in a xenograft model of human retinoblastoma. Photodiagnosis Photodyn Ther 6: 214-220.

16. Blanchard-Desce M, Brevet D, Durand JO, Garcia M, Gary-Bobo M, et al. (2011) Photosensibilisateurs biphotoniques, nanoparticules les contenant et leur utilisation comme médicaments. Patent cooperation treaty (PCT) WO 2011/073054 A1: 1-12

17. Liu S, Jones L, Gu FX (2012) Nanomaterials for ocular drug delivery. Macromo Biosci 12: 608-620.
Citation: Gallud A, Silva AD, Maynadier M, Basile I, Fontanel S, et al. (2013) Functionalized Nanoparticles for Drug Delivery, One- and Two-photon Photodynamic Therapy as a Promising Treatment of Retinoblastoma. J Clin Exp Ophthalmol 4: 288. doi:10.4172/2155-9570.1000288
Submit your next manuscript and get advantages of OMICS Group submissions

Unique features:

User friendly/feasible website-translation of your paper to 50 world's leading languages

Audio Version of published paper

Digital articles to share and explore

Special features:

250 Open Access Journal

20,000 editorial team

21 days rapid review process

- Quality and quick editorial, review and publication processing

- Indexing at PubMed (partial), Scopus, EBSCO, Index Copernicus and Google Scholar etc

- Sharing Option: Social Networking Enabled

- Authors, Reviewers and Editors rewarded with online Scientific Credits

- Better discount for your subsequent articles

Submit your manuscript at: www.editorialmanager.com/clinicalgroup 